University of Nebraska - Lincoln

DigitalCommons@University of Nebraska - Lincoln

June 1990

\title{
President Eisenhower, Economic Policy, and the 1960 Presidential Election
}

Ann Mari May

University of Nebraska - Lincoln, amay1@UNL.edu

Follow this and additional works at: https://digitalcommons.unl.edu/cbafacpub

Part of the Business Commons

May, Ann Mari, "President Eisenhower, Economic Policy, and the 1960 Presidential Election" (1990).

College of Business Faculty Publications. 24.

https://digitalcommons.unl.edu/cbafacpub/24

This Article is brought to you for free and open access by the Business, College of at DigitalCommons@University of Nebraska - Lincoln. It has been accepted for inclusion in College of Business Faculty Publications by an authorized administrator of DigitalCommons@University of Nebraska - Lincoln. 


\title{
President Eisenhower, Economic Policy, and the 1960 Presidential Election
}

\author{
AnN Mari May
}

This article examines economic policy in the Eisenhower years and the president's role in the 1960 election. I measure the impact of changes in fiscal policy on real GNP and show that policy in 1959 was unusually contractionary and cannot be dismissed as merely evidence of Eisenhower's fiscal conservatism.

dlai Stevenson once described the "liberal hour" as that time
before presidential elections when "even the most obsolete Republican becomes momentarily reconciled to the machine age." ${ }^{1}$ For the most fiscally conservative president of the postwar period the liberal hour never arrived. In the 1956 and 1960 presidential elections President Dwight D. Eisenhower refused to engage in expansionary policies to enhance his or his party's chances for re-election.

Eisenhower's refusal to stimulate the economy before either presidential election raises serious questions about the validity of the political business cycle hypothesis. ${ }^{2}$ According to this hypothesis, presidents will engage in contractionary policies in the early years of their terms to reduce inflation, then use expansionary policies before the presidential election to reduce unemployment and reap the electoral rewards of an expanding economy.

The economic policies of the Eisenhower administration provide a particularly intriguing case in the study of political business cycles because Eisenhower's policies were inconsistent with the general political business cycle pattern. Whereas real disposable income per capita increased in eight of eleven presidential and congressional election years during the administrations of Harry Truman, John Kennedy, Lyndon Johnson, Richard Nixon, and Gerald Ford, it declined in every election year during the Eisenhower administration. ${ }^{3}$ As Stephen Weatherford points out, Eisenhower provides the deviant case

The Journal of Economic History, Vol. L, No. 2 (June 1990). (C) The Economic History Association. All rights reserved. ISSN 0022-0507.

The author is Assistant Professor of Economics, University of Nebraska, Lincoln, NE 68588. She would like to thank Martha Olney for helpful comments on an earlier draft.

${ }^{1}$ Adlai E. Stevenson, Major Campaign Speeches of Adlai E. Stevenson (New York, 1953), pp. 31-32.

${ }^{2}$ For example, see William D. Nordhaus, "The Political Business Cycle,"' Review of Economic Studies, 42 (Apr. 1975), pp. 169-90; and Edward R. Tufte, Political Control of the Economy (Princeton, 1978).

3 Tufte, Political Control, p. 15. 
because "conditions were ripe for a political business cycle in 1954, 1958 , and 1960 , yet he explicitly abjured the temptation." 4

While Eisenhower had little need to stimulate the economy in 1956 with a solid lead in the polls over the Democratic front runner Adlai Stevenson, Vice President Richard Nixon could certainly have benefited from at least a momentary lapse in Eisenhower's fiscal frugality in 1960. Not only was the unemployment rate higher in 1960 than 1956, but the economy appeared to be sliding into another recession. ${ }^{5}$ Moreover, voter surveys from August 1959 through August 1960 showed Kennedy and Nixon virtually tied in the polls. ${ }^{6}$

There are, of course, various interpretations of Eisenhower's economic policy actions before the 1960 presidential election. Economists have generally dismissed them as evidence of his unflinching fiscal conservatism. ${ }^{7}$ Yet historians have consistently remarked upon the seeming ambivalence of Eisenhower toward Nixon's bid for the presidency in $1960 .^{8}$

This article examines fiscal policy during the Eisenhower administration and explores President Eisenhower's role in the 1960 election. Impact measures are developed that provide a more complete picture of policy changes and allow us to assess their effect on economic activity and to understand the complex array of factors influencing Eisenhower's policies before the 1960 election.

\section{OVERVIEW OF FISCAL POLICY IN THE EISENHOWER YEARS}

Reflecting upon the 1960 presidential campaign Nixon later wrote: "In a losing campaign, only the candidate is responsible for the tactics that led to defeat." "Henry Cabot Lodge apparently agreed. Upon viewing the first Nixon-Kennedy debate Lodge erupted: "That sonof-a-bitch just lost us the election!"'10 At other times, however, Nixon expressed the belief that the outcome of the election was the result of something beyond his control-the state of the economy. ${ }^{11}$

The downturn which began officially in the second quarter of 1960 was

\footnotetext{
${ }^{4}$ Stephen Weatherford, "The Interplay of Ideology and Advice in Economic Policy-Making: The Case of Political Business Cycles," Journal of Politics, 49 (Nov. 1987), p. 932.

5 The average annual unemployment rate in 1956 was 4.0 percent compared to an average annual rate of 5.4 percent in 1960. See the Economic Report of the President, 1988 (Washington, DC, 1988), p. 292.

${ }^{6}$ George H. Gallup, The Gallup Poll Public Opinion: 1935-71 (New York, 1972), pp. 1622, 1642, 1682.

${ }^{7}$ For example, see Herbert Stein, The Fiscal Revolution in America (Chicago, 1969).

${ }^{8}$ See Stephen E. Ambrose, Eisenhower: The President (New York, 1984); and Stephen E. Ambrose, Nixon: The Education of a Politician 1913-62 (New York, 1987).

${ }^{9}$ Richard M. Nixon, Six Crises (New York, 1962), p. 294.

${ }^{10}$ Fawn M. Brodie, Richard Nixon: The Shaping of His Character (Cambridge, MA, 1983), p. 427.

${ }^{11}$ Nixon, Six Crises, p. 310.
} 
certainly not a complete surprise to administration officials. In February 1960 Arthur Burns, chairman of the Council of Economic Advisors during the first Eisenhower administration, advised the vice president that the economy was heading for another contraction and suggested that "steps be taken immediately" to increase federal expenditures and loosen credit. ${ }^{12}$ Burns's advice was relayed to Eisenhower and discussed at the next Cabinet meeting.

Eisenhower did not take the advice. According to Nixon, the administration was unwilling to act to stimulate the economy until the downturn became more severe. ${ }^{13}$ In subsequent quarters, however, unemployment increased from an already high 5.2 percent in the second quarter to 6.2 percent in the fourth quarter of 1960 , and real GNP declined in the second, third, and fourth quarters. ${ }^{14}$ The Eisenhower administration chose to deal with the economic downturn by ignoring it. Throughout 1960, until his final budget message in January 1961, Eisenhower warned of the hazards of inflation and promised not to "undermine our strength as a nation through deficits." 15

Although Eisenhower was often accused of having a balanced budget fetish, he was, after all, a postwar Republican who, at least in principle, was willing to accept budget deficits during recessions. ${ }^{16}$ While the actual federal budget was in surplus when economic activity was expanding, it moved to a deficit during the three recessions of 1953$1954,1957-1958$, and 1960, and there was no attempt to raise taxes to offset the reduction in revenue associated with the downturn. ${ }^{17}$ In addition, although fiscal policy became more contractionary during the 1953-1954 recession, the full-employment budget showed a rather large deficit in early 1953. Likewise, while the full-employment budget was in surplus during the entire 1957-1958 recession, its size declined from $\$ 7.2$ billion in the third quarter of 1957 to $\$ 2.4$ billion by the fourth quarter of 1958.

Most interesting, however, is the full-employment budget for 1960 . The full-employment budget surplus rose to $\$ 15.1$ billion in the fourth quarter of 1960, its highest level of the entire Eisenhower term. Moreover, as the economy slid into recession, fiscal policy became tighter. The full-employment budget went from a surplus of $\$ 4.6$ billion in 1958 to a surplus of $\$ 14.7$ billion in 1960 .

\footnotetext{
12 Ibid., pp. 309-10.

13 Ibid., p. 310.

${ }^{14}$ Quarterly data from Fairmodel macroeconometric model, July 1985.

15 Public Papers of the Presidents of the United States, Dwight D. Eisenhower, 1960-61 (Washington, DC, 1961), p. 935.

${ }^{16}$ Stein, The Fiscal Revolution, pp. 281-84.

${ }^{17}$ All quarterly figures on the actual federal budget and the full-employment budget are reported in Keith Carlson, "Estimates of the High-Employment Budget: 1947-1967,' Federal Reserve Bank of St. Louis, Review, 49 (June 1967), pp. 10-11.
} 


\section{IMPACT MEASURES OF FISCAL POLICY}

While the full-employment budget provides a better measure of the thrust of fiscal policy than the actual federal budget, impact measures provide additional insight into the direction, magnitude, and composition of the changes in fiscal policy. ${ }^{18}$ These measures are generated using a macroeconometric model to estimate the impact of changes in fiscal policy in a given quarter on real GNP four quarters in the future. ${ }^{19}$

The aggregate fiscal policy impact measure is generated by comparing simulated real GNP with the actual changes in fiscal policy that occurred in a particular quarter against simulated real GNP without them. The influence of fiscal policy in time $t$ on real GNP $Y$, in period $t+j$ is thus:

$$
F_{y}^{j}(t)=Y_{t+j}-Y^{*}{ }_{t+j} \quad j \geq 0
$$

Ten fiscal policy variables are held constant in the $Y^{*}$ simulation. They are real federal government purchases of goods, personal income tax rate, profit tax rate, indirect business tax rate, employee social security tax rate, employer social security tax rate, civilian jobs, military jobs, transfer payments to households, and grants-in-aid to state and local governments. ${ }^{20}$

The results presented in Table 1 indicate that fiscal policy was highly contractionary in Eisenhower's first term. Although fiscal policy in 1953 was expansionary, increasing estimated real GNP by $\$ 8.8$ billion in 1954 , this largely reflected the influence of the Truman administration. ${ }^{21}$ The aggregate impact measures for 1954 reveal that fiscal policy was exceedingly contractionary, reducing estimated real GNP by $\$ 25.2$ billion in 1955. This represents the largest yearly decline of the Eisenhower tenure. Moreover, fiscal policy was contractionary in every quarter of 1954 - the only year in which this is true.

While contractionary policy in the early half of Eisenhower's first term is consistent with the political business cycle hypothesis, the impact measures do not indicate that fiscal policy became expansionary before the presidential election of 1956 . While fiscal policy was more expansionary in 1955 and 1956 than it was in 1954, it still reduced estimated real GNP by $\$ 5.1$ billion in 1956 and $\$ 490$ million in 1957.

\footnotetext{
${ }^{18}$ The method used to estimate the impact measures is presented in Alan S. Blinder and Stephen M. Goldfeld, "New Measures of Fiscal and Monetary Policy, 1958-1973," American Economic Review, 66 (Dec. 1976), pp. 780-96.

19 The four-quarter time horizon is used here because it represents a realistic impact lag and because the dynamic properties of the macroeconometric model produce highly correlated two-, four-, and six-quarter impact measures.

${ }^{20}$ See Ray C. Fair, Specification, Estimation, and Analysis of Macroeconometric Models (Cambridge, MA, 1984).

${ }^{21}$ When Eisenhower took office in 1953, government agencies were instructed to review their budgets and make cuts where possible. See the Public Papers of the Presidents of the United States, Dwight D. Eisenhower, 1953 (Washington, DC, 1960), pp. 53-54.
} 
TABLE 1

AGGREGATE FISCAL POLICY IMPACT MEASURES ON REAL GNP

(billions of dollars)

\begin{tabular}{|c|c|c|c|c|c|}
\hline \multirow[b]{2}{*}{ Year } & \multicolumn{4}{|c|}{ Quarters } & \multirow{2}{*}{$\begin{array}{l}\text { Yearly } \\
\text { Total }\end{array}$} \\
\hline & First & Second & Third & Fourth & \\
\hline 1953 & $\$ 3.885$ & $\$ 2.811$ & $\$-0.767$ & $\$ 2.852$ & $\$ \quad 8.781$ \\
\hline 1954 & -11.328 & -8.199 & -3.482 & -2.177 & -25.187 \\
\hline 1955 & -1.934 & -3.459 & 2.566 & -2.233 & -5.059 \\
\hline 1956 & -0.400 & 1.360 & -3.111 & 1.661 & -0.490 \\
\hline 1957 & 6.987 & 1.995 & -1.051 & 2.146 & 10.078 \\
\hline 1958 & 5.168 & 6.083 & 1.800 & 2.472 & 15.524 \\
\hline 1959 & -6.674 & -1.105 & -1.989 & 0.380 & -9.388 \\
\hline 1960 & -4.927 & 2.162 & 2.375 & 2.524 & 2.134 \\
\hline
\end{tabular}

Notes: The impact measure shows the effect of changes in fiscal policy on real GNP four quarters later. For example, fiscal policy in the first quarter of 1953 was expansionary, causing estimated real GNP in the first quarter of 1954 to be $\$ 3.88$ billion higher than it would have been otherwise. Sources: The impact measures were generated using the Fairmodel macroeconometric model, version 2.0, July 1985 .

In contrast, the aggregate impact measures indicate that fiscal policy was quite expansionary in 1957 and 1958, increasing estimated real GNP by $\$ 10.1$ and $\$ 15.5$ billion in succeeding years. However, more interesting is the result which shows that fiscal policy in 1959 was highly contractionary, causing estimated real GNP to decline by $\$ 9.4$ billion in the presidential election year of 1960. Furthermore, although fiscal policy was moderately expansionary in 1960 , most of the expansionary policies occurred late in the year and would not have had an impact on the economy until after the election.

The disaggregated impact measures provide more detailed information concerning fiscal policy changes. These measures are generated in a similar fashion to the aggregate ones and allow us to isolate the impact of a single policy variable on real GNP.

The disaggregated measures in Table 2 reveal that real federal purchases of goods were indeed highly contractionary in 1954, causing estimated real GNP to decline by $\$ 28.3$ billion. In addition, changes in military jobs exerted a contractionary influence early in Eisenhower's first term, reducing estimated real GNP $\$ 1.5$ billion and $\$ 2.2$ billion in 1954 and 1955. The reduction in federal purchases of goods and in military jobs reflects the decreased spending following the Korean conflict as well as the Eisenhower administration's attempt to reduce nondefense expenditures. In contrast, changes in transfer payments to households, personal income taxes, and indirect business taxes somewhat offset the contractionary influence of federal government purchases of goods.

In 1954 transfer payments to households increased estimated real GNP by a rather large $\$ 3.3$ billion. Although this may appear to indicate 
TABLE 2

DISAGGREGATED FISCAL POLICY IMPACT MEASURES ON REAL GNP (yearly totals in billions of dollars)

\begin{tabular}{|c|c|c|c|c|c|c|c|c|}
\hline Fiscal Policy & 1953 & 1954 & 1955 & 1956 & 1957 & 1958 & 1959 & 1960 \\
\hline $\begin{array}{l}\text { Federal Government } \\
\text { Purchases of } \\
\text { Goods }\end{array}$ & $\$ 8.390$ & $\$-28.304$ & $\$-2.819 \$$ & $0.013 \$$ & $\$ 3.701 \$$ & 8.381 & $\$-6.606 \$$ & 0.428 \\
\hline $\begin{array}{l}\text { Personal Income } \\
\text { Tax Rate }\end{array}$ & 0.164 & 0.994 & -0.156 & -0.385 & 0.065 & 0.306 & -0.328 & -0.369 \\
\hline Profit Tax Rate & 0.097 & 0.118 & -0.059 & 0.074 & 0.028 & -0.036 & 0.009 & 0.190 \\
\hline $\begin{array}{l}\text { Indirect Business } \\
\text { Tax Rate }\end{array}$ & 0.220 & 0.959 & -0.232 & -0.518 & 0.681 & 0.064 & -0.119 & -0.091 \\
\hline $\begin{array}{l}\text { Employee Social } \\
\text { Security Tax Rate }\end{array}$ & -0.032 & -0.283 & -0.070 & -0.114 & -0.265 & 0.019 & -0.290 & -0.489 \\
\hline $\begin{array}{l}\text { Employer Social } \\
\text { Security Tax Rate }\end{array}$ & 0.057 & -0.119 & -0.042 & -0.024 & -0.048 & 0.062 & -0.219 & -0.213 \\
\hline Civilian Jobs & -0.961 & -0.311 & 0.053 & 0.118 & -0.353 & 0.153 & 0.297 & -0.020 \\
\hline Military Jobs & -0.174 & -1.524 & -2.179 & -0.811 & -0.618 & -0.742 & -0.669 & 0.001 \\
\hline $\begin{array}{l}\text { Transfer Payments } \\
\text { to Households }\end{array}$ & 1.120 & 3.332 & 0.398 & 1.626 & 4.163 & 3.724 & 1.139 & 2.639 \\
\hline $\begin{array}{l}\text { Grants-in-aid to } \\
\text { State and Local } \\
\text { Governments }\end{array}$ & 0.000 & 0.004 & -0.002 & -0.001 & 0.000 & 0.011 & -0.009 & 0.003 \\
\hline
\end{tabular}

Sources: See Table 1.

that discretionary fiscal policy was expansionary, it reflects instead the influence of nondiscretionary changes resulting from the recession of 1953-1954. ${ }^{22}$

Changes in the personal income tax rate do, however, reflect discretionary fiscal policy, and the 1954 changes exerted the largest expansionary influence of any of the Eisenhower years-increasing estimated real GNP by $\$ 994$ million in 1955. This expansion does not, however, reflect countercyclical policy on the part of the Eisenhower administration. The reduction in personal income taxes was previously enacted by Congress and rather reluctantly signed into law by Eisenhower. ${ }^{23}$

Although the reduction in personal income taxes was offset somewhat by an increase in social security taxes in 1954, a reduction in excise taxes enacted by Congress and signed into law in March 1954 also exerted an expansionary impact on the economy. Changes in the excise tax rate during 1954 expanded estimated real GNP by $\$ 959$ million in 1955 - exerting the largest expansionary impact for that variable in any of the years reported. Although the reduction in excise taxes was instigated by Republicans in Congress as an antirecession action, the administration did not oppose the bill, given the state of the economy.

\footnotetext{
${ }^{22}$ Whereas other fiscal policy variables used here largely reflect discretionary changes in policy, transfer payments to households reflect both discretionary and nondiscretionary changes due to automatic stabilizers.

${ }^{23}$ See the Economic Report of the President, 1955 (Washington, DC, 1955), p. 19.
} 
This result confirms Herbert Stein's observation that the "excise tax cut was the largest stimulating fiscal action of 1954 which would not have been taken if there had been no recession." 24

The disaggregated measures provide further evidence that the contractionary policies before the 1956 presidential election were no accident. The largest expansionary influence of 1955 and 1956 came from transfer payments to households, which largely reflects nondiscretionary policy changes. All other changes in 1955, except that in civilian employment, exerted a contractionary influence on real GNP in the presidential election year of 1956.

Fiscal policy of 1957 and 1958 appears to have been quite expansionary, causing estimated real GNP to increase $\$ 10.1$ and $\$ 15.5$ billion. Although a significant proportion of the expansion was the result of increases in transfer payments to households and reflects the effect of automatic stabilizers, federal spending on goods was also expansionary. ${ }^{25}$ Federal expenditures were buoyed up by an increase in the purchase of farm commodities for farm price supports, acceleration in defense contract spending, and an increase in highway expenditures. ${ }^{26}$

While fiscal policy was expansionary in 1957 and 1958, it became unquestionably contractionary in 1959. The disaggregated measures indicate that federal purchases of goods in 1959 were such that estimated real GNP would decline by $\$ 6.6$ billion in 1960-the largest decline due to purchases for any year except the highly contractionary one of 1954. The decline in federal purchases of goods in part reflected a substantial reduction in defense-related expenditures. ${ }^{27}$ In addition, an increase in social security taxes in both 1959 and 1960 also depressed estimated real GNP.

In 1960 changes in federal government purchases of goods were more expansionary than in 1959, increasing estimated real GNP by a modest $\$ 428$ million. Most of the expansionary policies, however, came in the third quarter of 1960. Furthermore, the disaggregated figures show that increases in transfer payments to households provided most of the expansionary influence. Transfer payments to households in 1960 increased estimated real GNP by $\$ 2.6$ billion, up from $\$ 1.1$ billion the previous year due to the slowdown in economic activity in 1960 .

The fiscal policy impact measures, along with the full-employment budget figures, provide interesting grist for our analysis of economic policy in the 1950s. Both the full-employment budget and the impact measures indicate that the policies of the Eisenhower administration do

\footnotetext{
${ }^{24}$ Stein, The Fiscal Revolution, p. 305.

${ }^{25} \mathrm{~A}$ proportion of the increase in transfer payments to households was due to the legislative extension of unemployment compensation payments.

${ }^{26}$ See Wilfred Lewis, Federal Fiscal Policy in the Postwar Recessions (Washington, DC, 1962), pp. 208-13.

${ }^{27}$ Ibid., pp. 237-39.
} 
not correspond to the political business cycle pattern of contraction in the early years of the presidential term and expansion before the presidential election. Moreover, the fiscal policy impact measures show more clearly the highly contractionary character of policy in 1954 and 1959. While the contractionary policies of 1954 reflect the transition from a wartime to a peacetime economy, the economic policies before the 1960 election are less easily explained.

\section{THEMES OF CONTINUITY AND DISCONTINUITY}

Economists have traditionally dismissed the policies preceding the 1960 presidential election as evidence of Eisenhower's ongoing fiscal conservatism. While Eisenhower's undeniable commitment to Republican principles and his relentless budget surplus rhetoric made him appear to be "the rock of fiscal probity," the policies before the 1960 election cannot be dismissed as evidence of his conservatism. ${ }^{28}$

Throughout his tenure the president presented an unusually consistent theme reaffirming traditional Republican values and goals, chief among which was a belief in a minimal role for government in the economic sphere. For Eisenhower, this minimal role was inspired by the belief in the efficiency of the private sector in allocating resources and promoting economic growth. ${ }^{29}$ Minimal taxation was desirable so as not to stifle individual initiative or put undue pressure on financial markets. ${ }^{30}$ Moreover, the one goal which resonates throughout Eisenhower's papers is that of achieving economic growth without inflation. Maintaining a budget surplus was the primary mechanism through which low inflation was to be achieved.

Eisenhower's willingness to endure budget deficits became apparent during the 1953-1954 recession and again during the 1957-1958 recession. While it is no doubt true that a budget surplus had monumental significance to Eisenhower, as Stein points out, "the desirability of balancing the budget was not given by some eternal principle, but depended on economic conditions which would vary.,"31

In addition, the growing surpluses of the actual and full-employment budgets occurred in years when inflation became more problematic. In 1955,1956 , and 1957 the rate of inflation was above 3 percent, up from 1.6 percent in 1953 and 1954, and the full-employment budget surplus increased from $\$ 3.9$ billion in 1955 to $\$ 6.4$ billion in $1958 .^{32}$ Thus, Eisenhower's fiscal policy from 1953 through 1958 reflected consistent but flexible fiscal conservatism. The size of the budget surplus increased

\footnotetext{
28 Jonathan Hughes, American Economic Growth (Glenview, 1987), p. 513.

${ }^{29}$ Economic Report of the President, 1956 (Washington, DC, 1956), pp. 72-79.

${ }^{30}$ Public Papers of the Presidents, 1960-61, p. 40.

${ }^{31}$ Stein, The Fiscal Revolution, p. 283.

32 See the Economic Report of the President, 1988, p. 253.
} 
with inflation but not during periods of recession. Fiscal policy after 1958 , however, was quite different.

Both the actual and the full-employment budget figures indicate that fiscal policy became quite contractionary in 1959 and 1960. The actual federal budget went from a deficit of $\$ 10.3$ billion in 1958 to a surplus of $\$ 3.4$ billion in 1960 while the full-employment budget went from a surplus of $\$ 4.6$ billion in 1958 to a surplus of $\$ 14.7$ billion in $1960 .{ }^{33}$ The impact measures demonstrate that fiscal policy became exceedingly contractionary in 1959 , depressing estimated real GNP by $\$ 9.4$ billion in 1960.

This severely contractionary fiscal policy is not consistent with the flexible fiscal conservatism of the early Eisenhower years. Whereas increases in the budget surplus were associated with increases in inflation from 1955 through 1958, as it moderated in 1958, 1959, and 1960, the surplus continued to expand significantly. Furthermore, while increases in the unemployment rate brought about more moderate fiscal policy in the first six years of the Eisenhower administration, increases in unemployment in 1959 and 1960 were met with a more contractionary policy.

It might, of course, be argued that Eisenhower was unaware of the extent to which fiscal policy was contractionary in the period before the 1960 election. After all, the full-employment budget was a new concept in the late 1950s. Nevertheless, estimates of the full-employment budget were publicly available in 1960 . According to Stein, staff members of the Council of Economic Advisors presented estimates of the full-employment budget in 1960 and argued that the enlarged surplus was contributing to the sluggishness of the economy. ${ }^{34}$

Because fiscal policy is ultimately the result of the interaction of congressional as well as presidential action, it might be argued that fiscal policy reflected congressional rather than presidential influences. However, the contractionary fiscal policy in 1960 reflected the administration's conservative impulse more than the will of Congress. As Wilfred Lewis points out: "Congress showed far less enthusiasm for expenditure restraint in the 1960 election year than it had the year before, and appropriations were subsequently increased in virtually every category except foreign aid." 35

Nor can it be argued that monetary policy was to provide additional stimulus to offset contractionary fiscal policy. In the period before the 1960 election, monetary policy was also exceedingly contractionary. ${ }^{36}$ Furthermore, there appears to have been more agreement than dis-

${ }^{33}$ Carlson, "Estimates of the High-Employment Budget," pp. 10-11.

${ }^{34}$ Stein, The Fiscal Revolution, p. 364.

${ }^{35}$ Lewis, Federal Fiscal Policy, p. 240.

${ }^{36}$ See Milton Friedman and Anna J. Schwartz, A Monetary History of the United States, 1867-1960 (Princeton, 1963), pp. 617-20. 
agreement between the administration and the Federal Reserve on the thrust of monetary policy during this period. According to George Bach, "monetary authorities at the Federal Reserve by and large shared the White House view.",37

While economists have traditionally focused on Eisenhower's ideology as an explanation for the economic policies surrounding the 1960 presidential election, historians and others have often focused on the ambivalence of Eisenhower toward Nixon's presidential campaign. Stephen Ambrose, perhaps the most thorough of Eisenhower's biographers, attributes his attitude, at least in part, to his complex and often antagonistic relationship with the vice president. ${ }^{38}$

Fueling the speculation about his limited endorsement of Nixon in 1960 were various public comments by Eisenhower. On the eve of the 1960 presidential election, in perhaps his most famous press conference, Eisenhower was asked repeatedly what decisions Nixon had participated in as vice president. The president finally remarked: "If you give me a week, I might think of one. I don't remember." 39 Two weeks earlier, when asked about Nixon's view on nuclear testing, Eisenhower remarked, "I can't recall what he has ever said specifically about nuclear underground testing.",40

In reality, Eisenhower did very little to enhance the presidential prospects of Nixon and a great deal to jeopardize them. Under the guise of trying to further his vice president's career, Eisenhower suggested that Nixon take a Cabinet post to develop his administrative skills rather than remain on the ticket in $1956 .{ }^{41}$ In 1959 Eisenhower suggested changing the structure of the administration to include two "Assistant Presidents"- one in foreign affairs and one in domestic affairs. ${ }^{42}$ If, as Alben Barkley was fond of saying, the vice presidency wasn't worth a "bucket of warm spit," it would certainly be worth even less with this innovation.

Although Eisenhower did not dump Nixon in 1956 and did not pursue the "Assistant President"' idea in 1959, he also did not help Nixon raise campaign funds or endorse his candidacy until after the Republican Convention had nominated Nixon. ${ }^{43}$ Eisenhower remained a distant relative throughout most of the 1960 campaign. According to Nixon, it was Eisenhower who decided when it would be time to "move into action." 44 According to Eisenhower, however, it was Nixon who

\footnotetext{
${ }^{37}$ George L. Bach, Making Monetary and Fiscal Policy (Washington, DC, 1971), p. 102.

38 Ambrose, Nixon, p. 509.

${ }^{39}$ Public Papers of the Presidents, 1960-61, pp. 657-58.

40 Ibid., p. 626.

${ }^{41}$ For the official and unofficial story of this event, see Dwight D. Eisenhower, Waging Peace (Garden City, 1965), pp. 6-9; and Ambrose, Eisenhower, pp. 292-93.

42 Ambrose, Nixon, p. 511.

${ }^{43}$ Ambrose, Eisenhower, p. 512. Also see Public Papers of the Presidents, 1960-61, p. 144.

${ }^{44}$ Nixon, Six Crises, p. 349.
} 
"suggested he stay out of the active campaign until the last few days." 45 This, of course, was not the first time they had disagreed on who was making decisions.

\section{CONCLUDING REMARKS}

The Eisenhower presidency provides a compelling counterexample to the political business cycle hypothesis that presidents will manipulate the economy to enhance their re-election prospects. While Eisenhower engaged in highly contractionary policies upon entering office, he did not engage in significantly expansionary policies before the 1956 and 1960 presidential elections.

Economists have generally been satisfied with attributing these economic policies to Eisenhower's fiscal conservatism. For many, "Eisenhower epitomized the chief executive who sets an economic policy course early in the administration and holds tightly" to its central tenets. ${ }^{46}$ The evidence presented here, however, indicates that the highly contractionary fiscal policy before the 1960 presidential election is not consistent with the flexible fiscal conservatism exhibited throughout much of the Eisenhower presidency.

Instead, the evidence on fiscal policy is consistent with those interpretations that view fiscal policy before the 1960 election as an anomaly-possibly influenced by Eisenhower's relationship with Nixon. As Ambrose has observed: "Time and again, Eisenhower could have done things that Nixon urged on him that could have swayed votes, but he always refused." ${ }^{47}$ It is clear that for Eisenhower as for other presidents, ideology alone provides an insufficient explanation for policy actions which must be understood in the context of other political, economic, social, and, perhaps, personal factors.

\footnotetext{
45 Ambrose, Nixon, p. 558.

46 Weatherford, "The Interplay of Ideology," p. 944.

47 Ambrose, Nixon, p. 513.
} 